\title{
Kinetics and mechanism of the ligand substitution reaction of di- $\mu$-hydroxobis(bipyridyl)dipalladium(II) ion with diethyldithiocarbamate anion in aqueous solution
}

\author{
SUBHASIS MALLICK, BIPLAB K BERA, SUBALA MONDAL, PARNAJYOTI KARMAKAR, \\ ARUP MANDAL and ALAK K GHOSH* \\ Department of Chemistry, The University of Burdwan, Burdwan 713104, India \\ e-mail: alakghosh2002@yahoo.co.in
}

MS received 21 April 2010; revised 21 December 2010; accepted 17 January 2011

\begin{abstract}
The kinetics of the interaction between diethyldithiocarbamate ( $\left.\mathrm{Et}_{2} \mathrm{DTC}\right)$ and the title complex has been studied spectrophotometrically in aqueous medium as a function of nucleophile concentration, temperature and $\mathrm{pH}$ at constant ionic strength. The reaction is a two-step process in which the first step is liganddependent, but the second step is ligand-independent and is assigned to ring closure. The rate and activation parameters, conductivity studies and IR data were used to deduce a plausible mechanism.
\end{abstract}

Keywords. Kinetics; palladium(II); diethyldithiocarbamate; mechanism; activation parameters.

\section{Introduction}

Cisplatin is one of the most active antitumour agents in clinical use ${ }^{1}$ but its clinical use is limited by undesirable side effects, including nephrotoxicity, ototoxicity, neurotoxicity, nausea, vomiting and myelosuppression. ${ }^{2,3} \mathrm{Pd}(\mathrm{II})$ and $\mathrm{Pt}(\mathrm{II})$ complexes have the same structure, with a five orders of magnitude higher reactivity in the case of Pd(II) complexes, but similar thermodynamic parameters. Pd(II) complexes are good models for the analogous $\mathrm{Pt}(\mathrm{II})$ complexes in solution.

Much work has been performed on the equilibrium studies of palladium(II) complexes with aliphatic amines $^{4-7}$ and it is of interest to extend this work to the reactions of palladium(II) complexes with heterocycles, such as 2,2'-bipyridine. Aromatic heterocycles generally act as $\sigma$-donors and also function as fairly effective $\pi$-acceptors. In addition, heterocycles can be involved in $\pi-\pi$ stacking with purine and pyrimidine bases. This can lead to complex formation with DNA subunits, which is an important target in cancer chemotherapy. ${ }^{8}$ Besides this, non-covalent interaction of palladium complexes with nucleic acids is also possible. ${ }^{9}$ This type of non-covalent interaction may inhibit the reactivity of the metal complexes. ${ }^{10}$

The sulphur-containing ligands have high affinity for $\mathrm{Pd}(\mathrm{II})$ and $\mathrm{Pt}(\mathrm{II})$. These ligands will compete with

\footnotetext{
${ }^{*}$ For correspondence
}

the DNA for the reaction with any antitumour agent. Therefore, it is of biological significance to evaluate the equilibrium constants for the displacement reaction. These equilibrium constants may give a measure of the effectiveness of the antitumour agent.

Diethyldithiocarbamate is an effective chemoprotective agent and is the only chemoprotector effective when administered 1-4h after cisplatin. ${ }^{11,12}$ Moreover the dithiocarbamato derivatives of $\mathrm{Pd}(\mathrm{II})$ and Pt(II) complexes, containing 2,2'-bipyridyl and 1,10phenanthroline as a ligand showed antitumor activity against leukemic cells. ${ }^{13}$

In view of the above, we now describe the interaction of a palladium(II) complex towards Nadiethyldithiocarbamate ( $\left.\mathrm{NaEt}_{2} \mathrm{DTC}\right)$ which may throw some light on the bioinorganic chemistry of palladium(II).

\section{Experimental}

\subsection{Materials}

$\left[\mathrm{Pd}(\right.$ bipy $\left.) \mathrm{Cl}_{2}\right]$ (bipy $=2,2^{\prime}$-bipyridine) was prepared by literature methods. ${ }^{14,15}$ The diaqua complex, $\left[\mathrm{Pd}(\right.$ bipy $\left.)\left(\mathrm{H}_{2} \mathrm{O}\right)_{2}\right]\left(\mathrm{ClO}_{4}\right)_{2}$, was prepared in solution by the method of Hay and Basak ${ }^{16}$ by stirring the chloro complex with two mole equivalents of $\mathrm{AgClO}_{4}$ followed by keeping it overnight (with careful protection 
from light). The precipitated $\mathrm{AgCl}$ was removed by filtration and the filtrate made up to the requisite volume in a standard flask.

The reactant complex, di- $\mu$-hydroxobis(bipyridyl) dipalladium(II) ion (complex 1), was obtained in situ by adjusting the $\mathrm{pH}$ to 7.4 with $\mathrm{NaOH} / \mathrm{HClO}_{4}$. The reaction product of diethyldithiocarbamate and complex $\mathbf{1}$ was prepared by mixing the reactants in different ratios, namely, 1:1, 1:2, 1:3, 1:5, and 1:10, and keeping at $50^{\circ} \mathrm{C}$ for $24 \mathrm{~h}$. The absorbance spectra of these mixtures (figure 1) all exhibited the same $\lambda_{\max }$ with nearly identical intensities.

The starting complex does not react well with azide, cytidine or with thymidine, but easily reacts with sulphur-containing molecules such as cysteine, thiosemicarbazide, methionine etc. So we may say that the sulphur atom of the ligand is involved in bonding with Pd(II) due to soft nature of both atoms.

From the above discussion, the possible structure of the product complex can be represented as in scheme 1 .

\subsection{Product analysis}

The composition of the product was determined by Job's method of continuous variation, which indicated a 2: 1 metal-ligand ratio (figure 2).

The IR spectrum of the product in $\mathrm{KBr}$ disc indicates the presence of a coordinated hydroxide group is confirmed ${ }^{17,18}$ by the $\mathrm{OH}$ stretching absorption at $c a$. $3400 \mathrm{~cm}^{-1}$. Absorption peak at $c a .1030 \mathrm{~cm}^{-1}$ assigned as the bending mode and peak at $c a .575 \mathrm{~cm}^{-1}$ assigned

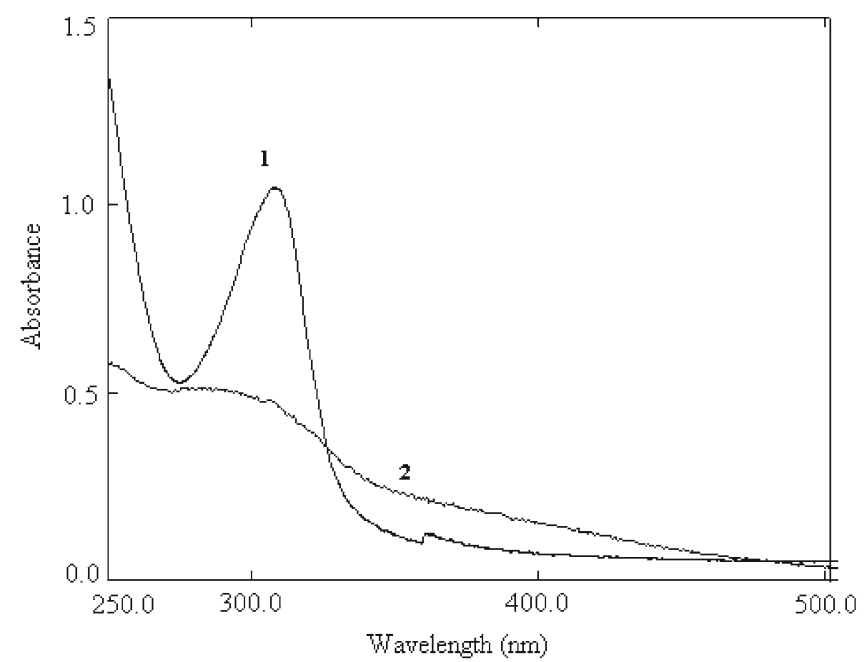

Figure 1. Spectra of the starting [complex 1] (1), and the diethyldithiocarbamate substituted complex (2); [ complex 1] $=2.85 \times 10^{-4} \mathrm{~mol} \mathrm{dm}^{-3},\left[\mathrm{Et}_{2} \mathrm{DTC}\right]=5.7 \times$ $10^{-3} \mathrm{~mol} \mathrm{dm}^{-3}, \mathrm{pH}=7.4$, cell used $=1 \mathrm{~cm}$ quartz.

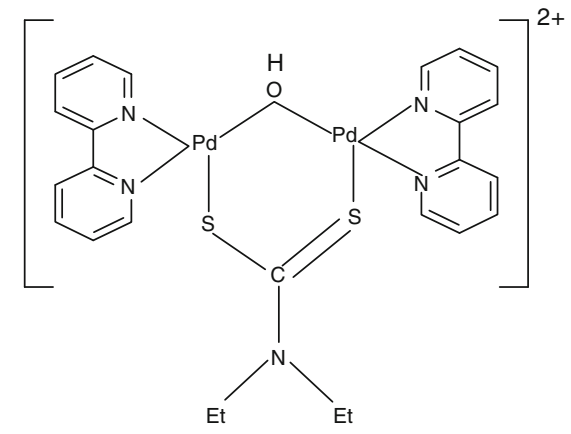

Scheme 1. Possible structure of the product complex.

as the $\mathrm{Pd}-\mathrm{O}$ stretching vibration for a bridging hydroxide group. ${ }^{19}$ From this, we may conclude that there is a bridged $\mathrm{OH}$ group in the resultant product complex. For this complex the $\delta(\mathrm{OH})$ mode is obscured by the intense anion absorption. The bands in the region of $c a$. $940-1010 \mathrm{~cm}^{-1}$ were attributed to the stretching mode of the $\mathrm{C}-\mathrm{S}$ bond. The position of this band has been used as a criterion for symmetric or asymmetric coordination of the dithiocarbamato group. The singlet in the IR spectrum confirms the equivalence of the $\mathrm{S}$ atom, but the doublet at $c a .987 \mathrm{~cm}^{-1}$ in the IR spectrum indicates non-equivalence of the $\mathrm{S}$ atoms in the compound. Presence of doublet at $940-1010 \mathrm{~cm}^{-1}$ indicates nonequivalence of two sulphur atoms. So we can say that both $\mathrm{S}$ atoms of the ligand involved in bonding. The presence of $\gamma(\mathrm{Pd}-\mathrm{S})$ band in the $300-400 \mathrm{~cm}^{-1}$ region confirms the coordination of the ligand to Pd(II) via sulphur atom. ${ }^{20}$ Broad and strong bands at $c a .1089$ and at ca. $627 \mathrm{~cm}^{-1}$ are assigned to the perchlorate salt of the complex (figure 3 ).

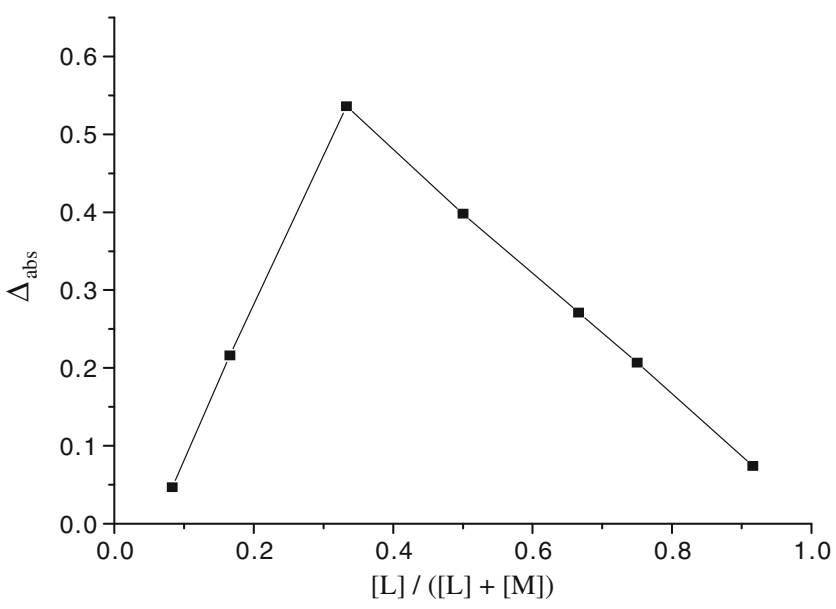

Figure 2. Job's plot for the reaction of complex 1 with $\mathrm{Et}_{2}$ DTC. 


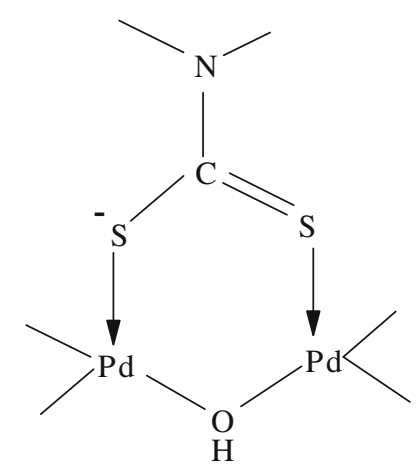

Figure 3. Coordination modes of the ligand.

Conductance measurements also help us to identify the product. During the course of the reaction, there is release of $\mathrm{OH}^{-}$ion, as shown by increase in conductance and $\mathrm{pH}$. This is consistent with substitution of $\mathrm{OH}^{-}$by $\mathrm{Et}_{2} \mathrm{DTC}$.

\subsection{Measurements}

The $\mathrm{pH}$ of the solution was adjusted by adding $\mathrm{NaOH} / \mathrm{HClO}_{4}$, and the $\mathrm{pH}$ measurements were made with a Sartorius digital $\mathrm{pH}$ meter (model PB11) with an accuracy of \pm 0.01 units. Doubly distilled water was used to prepare all the solutions. All other chemicals used were of AR grade. The reactions were carried out at constant ionic strength $\left(0.1 \mathrm{~mol} \mathrm{dm}^{-3} \mathrm{NaClO}_{4}\right)$.

Spectroscopic measurements were made with a Shimadzu UV-VIS Spectrophotometer (UV-2101). IR Spectra ( $\mathrm{KBr}$ disc, $4000-300 \mathrm{~cm}^{-1}$ ) were measured on a Perkin-Elmer FTIR RX1 Spectrophotometer. Conductance measurements were made with a Systronics conductivity meter (model 308), where the cell constant was calibrated with $0.01 \mathrm{M} \mathrm{KCl}$ solution and water used as solvent.

The kinetic studies were done on a Shimadzu UV 2101 PC Spectrophotometer attached to a thermoelectric cell temperature controller (Model Shimadzu TB 85 thermobath, accuracy $\pm 0.1^{\circ} \mathrm{C}$ ). The development of a characteristic peak of the product complex (complex 2) at $310 \mathrm{~nm}$ was monitored with time at different fixed temperatures. The conventional mixing technique was followed and pseudo first order conditions were employed throughout.

The plots of $\ln \left(A_{t}-A_{\infty}\right)$, where $A_{t}$ and $A_{\infty}$ are absorbances at time $t$ and after the completion of the reaction, against time were found to be nonlinear, being curved at the initial stage and subsequently of constant slope (figure 4).

The method of Weyh and Hamm ${ }^{21}$ was adopted to calculate rate constants for two consecutive steps.

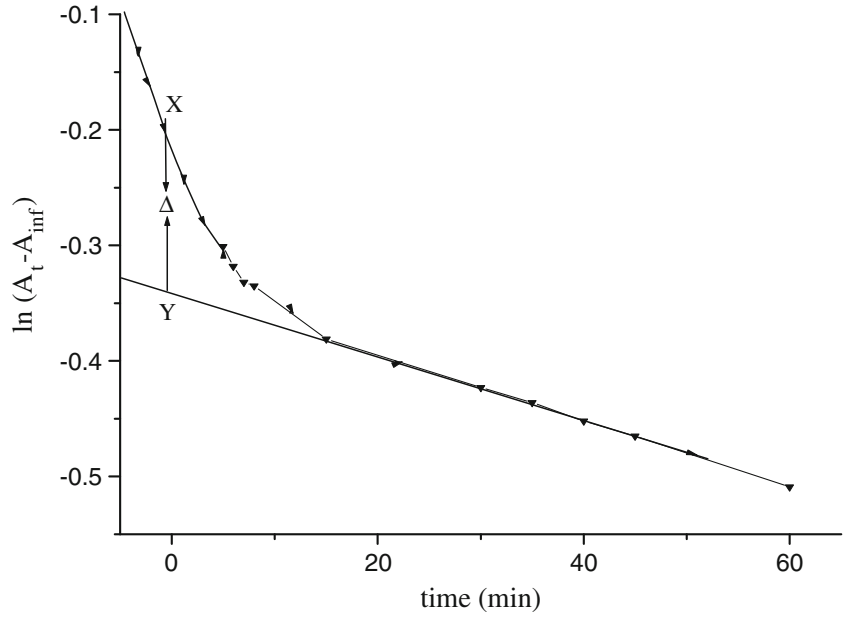

Figure 4. A typical plot of $\ln \left(\mathrm{A}_{t}-\mathrm{A}_{\infty}\right)$ versus time. [complex 1] $=2.85 \times 10^{-4} \mathrm{~mol} \mathrm{dm}^{-3}$. [Et $\left.{ }_{2} \mathrm{DTC}\right]=5.7 \times$ $10^{-3} \mathrm{~mol} \mathrm{dm}^{-3}, \mathrm{pH}=7.4$, temp $=35^{\circ} \mathrm{C}$.

From the linear second portion, $\mathrm{k}_{2}$ values were obtained. The $\mathrm{k}_{1(\mathrm{obs})}$ values were obtained from the plot of $\ln \Delta$ versus t. A typical plot is shown in figure 5 . Rate data represented as an average of duplicate runs are reproducible within $\pm 4 \%$.

\section{Results and discussion}

The $\mathrm{pKa}$ value of the ligand $\mathrm{Et}_{2} \mathrm{DTC}$ is 3.37 at $25^{\circ} \mathrm{C},{ }^{22}$ so that at $\mathrm{pH} 7.4$, the major species involved in the kinetic process is the anionic form of the ligand which is $\mathrm{Et}_{2} \mathrm{DTC}^{-}$. The $\mathrm{pKa}_{1}$ and $\mathrm{pKa}_{2}$ values for $\left[\mathrm{Pd}(\text { bipy })\left(\mathrm{H}_{2} \mathrm{O}\right)_{2}\right]^{2+}$ as reported in the literature are 4.5 and 9.6 at $25^{\circ} \mathrm{C}$ respectively $^{23}$ and 3.91 and 8.39 at $25^{\circ} \mathrm{C}$ respectively. ${ }^{5}$

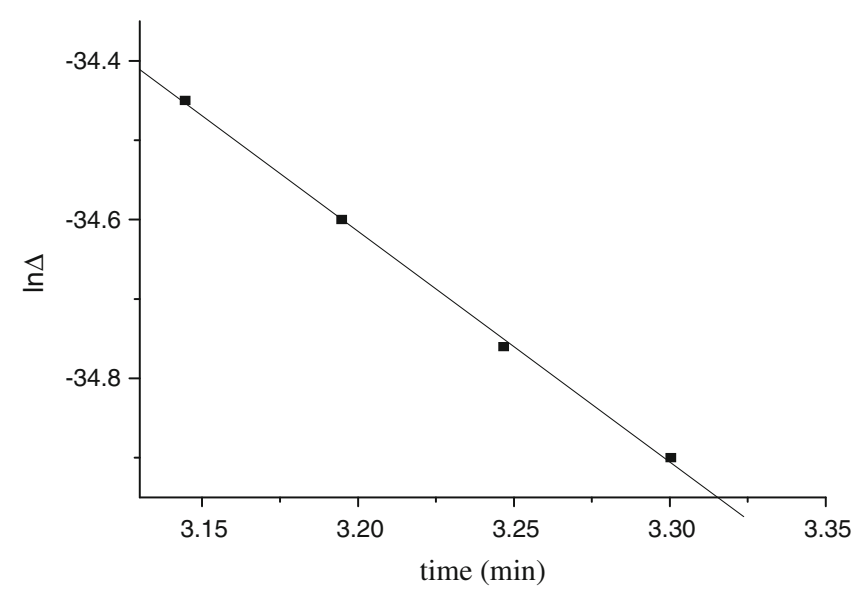

Figure 5. A typical plot of $\ln \Delta$ versus time. [complex 1] $=$ $2.85 \times 10^{-4} \mathrm{~mol} \mathrm{dm}^{-3}$. $\left[\mathrm{Et}_{2} \mathrm{DTC}\right]=5.7 \times 10^{-3} \mathrm{~mol} \mathrm{dm}^{-3}$. $\mathrm{pH}=7.4$, temp $=35^{\circ} \mathrm{C}$. 
We can consider the following equilibria to be in operation:

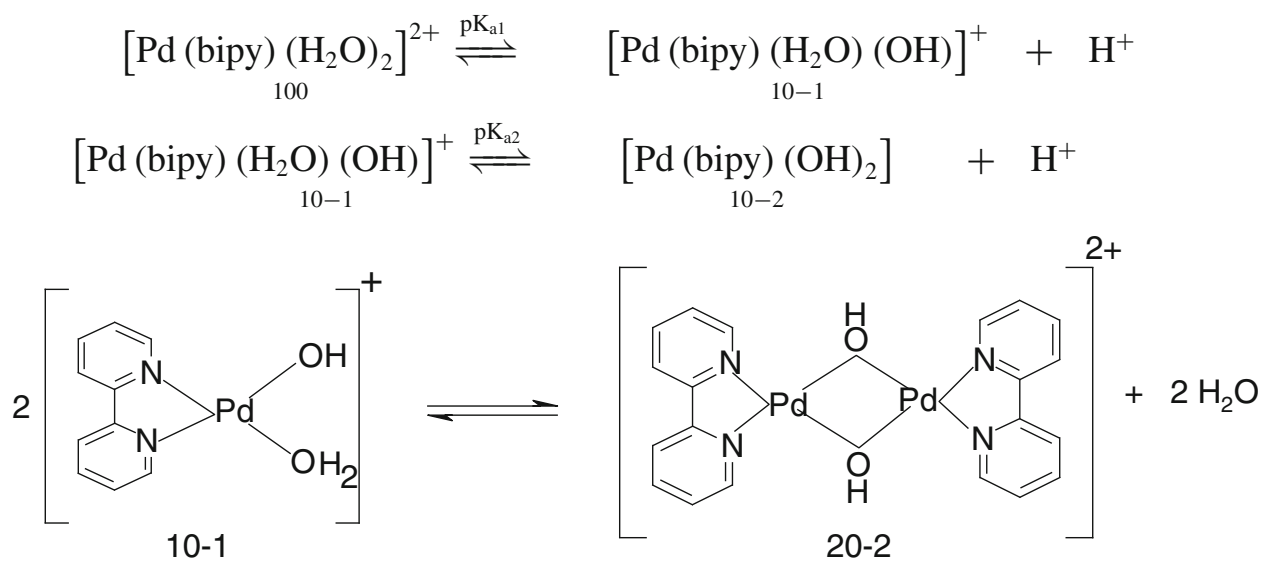

The equilibrium constant ${ }^{5}$ for the dimerization step (3), $\log \mathrm{K}_{\text {dimer }}=3.12$. At $\mathrm{pH} 7.4$, the protonation state of the Pd complex will be primarily the hydroxoaqua (10-1). From the $\mathrm{pK}_{a}$ values and from the dimerization constant, it can be shown that at $\mathrm{pH} 7.4$ the percentage of the dimer present in the solution is $\sim 85 \%$. This is supported widely in the literature. ${ }^{24-26}$

The plot of $\ln \left(\mathrm{A}_{\mathrm{t}}-\mathrm{A}_{\infty}\right)$ versus time, indicates that the reaction is not a single-step process. A two-step consecutive process may be assumed, the first step being dependent and the final step independent of the concentration of dithiocarbamate.

The rate constant for such a process can be evaluated by assuming the following scheme 2 .

where $\mathrm{A}$ is the hydroxo-bridged dimer, $\mathrm{B}$ is as intermediate with diethyldithiocarbamate and $\mathrm{C}$ is the final product complex $\left[\mathrm{Pd}_{2}(\text { bipy })_{2}(\mathrm{OH})(\mathrm{L})\right]$.

The rate constant $\mathrm{k}_{1 \text { (obs) }}$ for the $\mathrm{A} \rightarrow \mathrm{B}$ step can be evaluated by the method of Weyh and Hamm using the usual consecutive rate law:

$$
\left(\text { At }-\mathrm{A}_{\infty}\right)-\mathrm{a}_{2} \exp \left(-\mathrm{k}_{2} \mathrm{t}\right)=\mathrm{a}_{1} \exp \left(-\mathrm{k}_{1(\mathrm{obs})} \mathrm{t}\right),
$$

where $a_{1}$ and $a_{2}$ are constants dependent on the rate constants and extinction coefficient.

Values of $\left[\left(A_{t}-A_{\infty}\right)-a_{2} \exp \left(-k_{2} t\right)\right]$ were obtained from $\mathrm{X}-\mathrm{Y}$ at different times (figure 3 ). Then,

$$
\ln \Delta=\text { constant }-\mathrm{k}_{1(\text { obst })} \mathrm{t} \text {. }
$$

The value of $\mathrm{k}_{1 \text { (obs) }}$ was derived from the slope of a plot of $\ln \Delta$ versus $t$ (where $t$ is small) (figure 5). A similar procedure was applied for each $\mathrm{Et}_{2} \mathrm{DTC}$ concentration in the $2.85 \times 10^{-3}$ to $8.55 \times 10^{-3} \mathrm{~mol} \mathrm{dm}^{-3}$ range, at constant [1] $\left(2.85 \times 10^{-4} \mathrm{~mol} \mathrm{dm}^{-3}\right)$ at $\mathrm{pH}=7.4, \mu=$ $0.1 \mathrm{~mol} \mathrm{dm}^{-3} \mathrm{NaClO}_{4}$ and at different temperatures namely $30,35,40$ and $45^{\circ} \mathrm{C}$. The $\mathrm{k}_{1(\mathrm{obs})}$ values are presented in table 1.

The rate increases with increase in $\left[\mathrm{Et}_{2} \mathrm{DTC}\right]$ before reaching a limiting value (figure 6), which is probably due to the completion of the outer sphere association complex formation. At this stage, the interchange of the ligands from the outer sphere to the inner sphere occurs, i.e., dithiocarbamato attacks one of the $\mathrm{Pd}(\mathrm{II})$ atoms of the dihydroxo- bridged dimer to give intermediate complex.

From the experimental findings, scheme 3 may be given for the $\mathrm{A} \rightarrow \mathrm{B}$ step.

Based on scheme 3, a rate expression can be derived for the A $\rightarrow$ B step.

$$
\begin{gathered}
\mathrm{d}[\mathrm{B}] / \mathrm{dt}=\mathrm{k}_{1} \mathrm{~K}_{\mathrm{E}}[\mathrm{B}]\left[\mathrm{Et}_{2} \mathrm{DTC}^{-}\right] /\left(1+\mathrm{K}_{\mathrm{E}}\left[\mathrm{Et}_{2} \mathrm{DTC}^{-}\right]\right) \\
\mathrm{d}[\mathrm{B}] / \mathrm{dt}=\mathrm{k}_{1(\mathrm{obs})}[\mathrm{B}]_{\mathrm{T}},
\end{gathered}
$$

where T stands for total concentration of Pd(II).Thus, it can be written as

$$
\mathrm{k}_{1(\mathrm{obs})}=\mathrm{k}_{1} \mathrm{~K}_{\mathrm{E}}\left[\mathrm{Et}_{2} \mathrm{DTC}^{-}\right] /\left(1+\mathrm{K}_{\mathrm{E}}\left[\mathrm{Et}_{2} \mathrm{DTC}^{-}\right]\right),
$$

where $k_{1}$ is the rate constant for the formation of intermediate (B) from dihydroxy dimer (A), $\mathrm{K}_{E}$ is the outer sphere association equilibrium constant. 


$$
\mathrm{A} \stackrel{\mathrm{k}_{1}}{\rightarrow} \mathrm{B} \stackrel{\mathrm{k}_{2}}{\rightarrow} \mathrm{C}
$$

Scheme 2.

Table 1. $10^{3} \mathrm{k}_{1 \text { (obs) }}\left(\mathrm{s}^{-1}\right)$ values for different $\mathrm{Et}_{2} \mathrm{DTC}$ concentrations at different temperatures. [complex 1] $=2.85 \times$ $10^{-4} \mathrm{~mol} \mathrm{dm}^{-3}, \mathrm{pH}=7.4$, ionic strength $=0.1 \mathrm{~mol} \mathrm{dm}^{-3}$ $\mathrm{NaClO}_{4}$.

\begin{tabular}{lcccc}
\hline \multirow{2}{*}{$\begin{array}{l}10^{3}\left[\mathrm{Et}_{2} \mathrm{DTC}\right] \\
\left(\mathrm{mol} \mathrm{dm}^{-3}\right)\end{array}$} & \multicolumn{4}{c}{ Temperature $\left({ }^{\circ} \mathrm{C}\right)$} \\
\cline { 2 - 5 } & 30 & 35 & 40 & 45 \\
\hline 2.85 & 2.00 & 2.12 & 2.87 & 3.10 \\
4.27 & 2.37 & 2.85 & 3.20 & 3.90 \\
5.70 & 2.59 & 3.14 & 3.70 & 4.18 \\
7.12 & 2.75 & 3.25 & 3.80 & 4.70 \\
8.55 & 2.98 & 3.33 & 4.12 & 5.16 \\
\hline
\end{tabular}

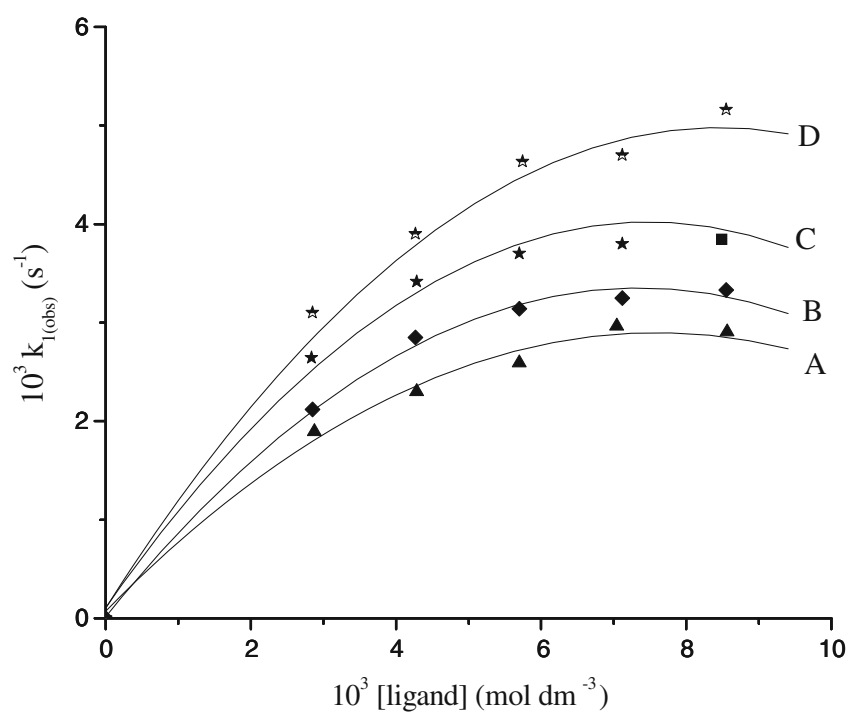

Figure 6. Plot of $\mathrm{k}_{1 \text { (obs) }}$ versus $\left[\mathrm{Et}_{2} \mathrm{DTC}\right]$ at different temperatures. $\mathrm{A}=30, \mathrm{~B}=35, \mathrm{C}=40$ and $\mathrm{D}=45^{\circ} \mathrm{C}$.

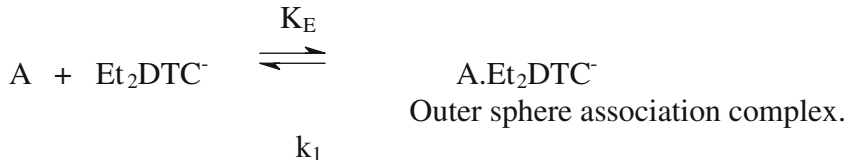

$$
\begin{aligned}
& \mathrm{A} \mathrm{Et}_{2} \mathrm{DTC}^{-} \stackrel{\mathrm{k}_{1}}{\rightarrow} \mathrm{B}
\end{aligned}
$$

Scheme 3. Formation of intermediate complex.

The equation can be written as

$$
1 / \mathrm{k}_{1(\mathrm{obs})}=1 / \mathrm{k}_{1}+1 / \mathrm{k}_{1} \mathrm{~K}_{\mathrm{E}}\left[\mathrm{Et}_{2} \mathrm{DTC}^{-}\right] \text {. }
$$

The plot of $1 / \mathrm{k}_{1(o b s)}$ versus $1 /$ [ $\left.\mathrm{Et}_{2} \mathrm{DTC}^{-}\right]$should be linear (figure 7) with an intercept of $1 / \mathrm{k}_{1}$ and slope $1 / \mathrm{k}_{1} \mathrm{~K}_{E}$.

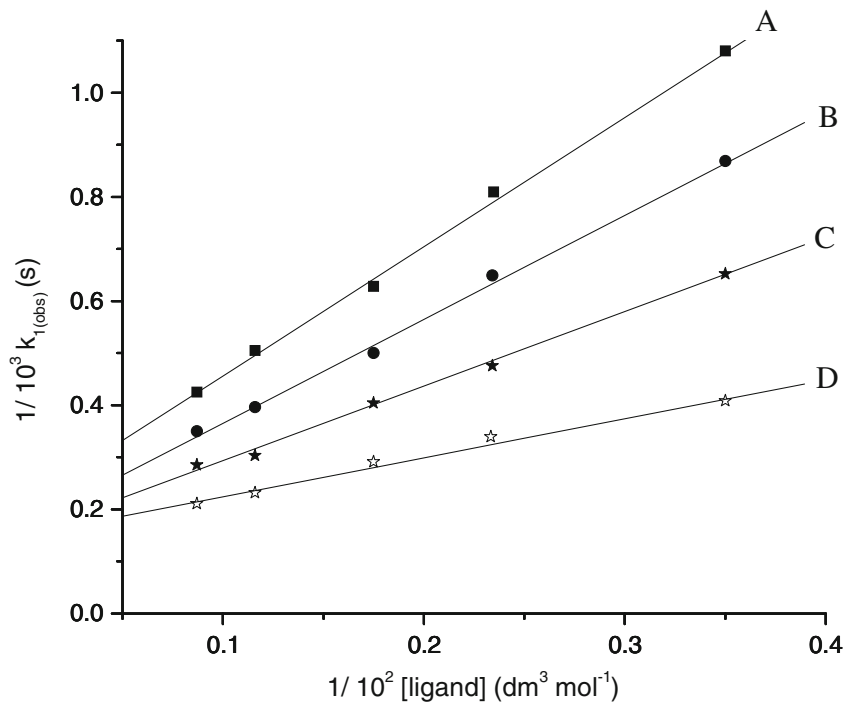

Figure 7. Plot of $1 / \mathrm{k}_{1(\mathrm{obs})}$ versus $1 /\left[\mathrm{Et}_{2} \mathrm{DTC}\right]$ at different temperatures, $\mathrm{A}=30, \mathrm{~B}=35, \mathrm{C}=40$ and $\mathrm{D}=45^{\circ} \mathrm{C}$.

Table 2. $10^{3} \mathrm{k}_{1}\left(\mathrm{~s}^{-1}\right)$ and $\mathrm{K}_{\mathrm{E}}\left(\mathrm{dm}^{3} \mathrm{~mol}^{-1}\right)$ values for different ligands at different temperatures. [complex 1] $=$ $2.85 \times 10^{-4} \mathrm{~mol} \mathrm{dm}^{-3}, \mathrm{pH}=7.4$, ionic strength $=$ $0.1 \mathrm{~mol} \mathrm{dm}^{-3} \mathrm{NaClO}_{4}$.

\begin{tabular}{lcc}
\hline Temperature $\left({ }^{\circ} \mathrm{C}\right)$ & $10^{3} \mathrm{k}_{1}\left(\mathrm{~s}^{-1}\right)$ & $\mathrm{K}_{\mathrm{E}}\left(\mathrm{dm}^{3} \mathrm{~mol}^{-1}\right)$ \\
\hline 30 & 5.25 & 110 \\
35 & 5.85 & 130 \\
40 & 6.52 & 165 \\
45 & 7.26 & 199 \\
\hline
\end{tabular}

Table 3. $10^{5} \mathrm{k}_{2}\left(\mathrm{~s}^{-1}\right)$ values for different $\mathrm{Et}_{2} \mathrm{DTC}$ concentrations at different temperatures. [complex 1] $=2.85 \times$ $10^{-4} \mathrm{~mol} \mathrm{dm}^{-3}, \mathrm{pH}=7.4$, ionic strength $=0.1 \mathrm{~mol} \mathrm{dm}^{-3}$ $\mathrm{NaClO}_{4}$.

\begin{tabular}{lcccc}
\hline \multirow{2}{*}{$\begin{array}{l}10^{3}\left[\mathrm{Et}_{2} \mathrm{DTC}\right] \\
\left(\mathrm{mol} \mathrm{dm}^{-3}\right)\end{array}$} & \multicolumn{4}{c}{ Temperature $\left({ }^{\circ} \mathrm{C}\right)$} \\
\cline { 2 - 5 } & 30 & 35 & 40 & 45 \\
\hline 2.85 & 8.91 & 9.85 & 10.59 & 11.47 \\
4.27 & 8.93 & 9.86 & 10.60 & 11.47 \\
5.70 & 8.94 & 9.86 & 10.61 & 11.49 \\
7.12 & 8.93 & 9.86 & 10.59 & 11.49 \\
8.55 & 8.94 & 9.87 & 10.61 & 11.48 \\
\hline
\end{tabular}

This was found to be at different temperatures studied.

The $\mathrm{k}_{1}$ and $\mathrm{K}_{E}$ values obtained from the intercept and slope to intercept ratios are given in table 2 .

The $\mathrm{B} \rightarrow \mathrm{C}$ step is intramolecular ring closure and is independent of $\mathrm{Et}_{2} \mathrm{DTC}$ concentration. At a particular 
Table 4. Activation and thermodynamic parameters of [complex 1] by various ligands in aqueous medium, $\mathrm{pH}=7.4$.

\begin{tabular}{lccccc}
\hline Ligand & $\begin{array}{c}\Delta \mathrm{H}_{1}^{\neq} \\
\left(\mathrm{kJ} \mathrm{mol}^{-1}\right)\end{array}$ & $\begin{array}{c}\Delta \mathrm{S}_{1}^{\neq} \\
\left(\mathrm{J} \mathrm{K}^{-1} \mathrm{~mol}^{-1}\right)\end{array}$ & $\begin{array}{c}\Delta \mathrm{H}_{2}^{\neq} \\
\left(\mathrm{kJmol}^{-1}\right)\end{array}$ & $\begin{array}{c}\Delta \mathrm{S}_{2}^{\neq} \\
\left(\mathrm{J} \mathrm{K}^{-1} \mathrm{~mol}^{-1}\right)\end{array}$ & Refs. \\
\hline DL-methionine & $46.0 \pm 1.5$ & $-101 \pm 5$ & $\mathrm{a}$ & $\mathrm{a}$ & 27 \\
Thiosemicarbazide & $50.4 \pm 1.9$ & $-105 \pm 6$ & $\mathrm{a}$ & $\mathrm{a}$ & 28 \\
L-cysteine & $33.6 \pm 1.5$ & $-134 \pm 5$ & $\mathrm{a}$ & $\mathrm{a}$ & 29 \\
Thiourea & $24.2 \pm 1.6$ & $-210 \pm 5$ & $7.5 \pm 1.0$ & $-306 \pm 6$ & 30 \\
Dithiocarbamate & $15 \pm 1.2$ & $-239 \pm 5$ & $10.4 \pm 1.5$ & $-288 \pm 4$ & This work \\
\hline
\end{tabular}

a Previous studies indicated a single step reaction, but we have found a two-step reaction for the present system

${ }^{\mathrm{b}} \Delta \mathrm{H}_{1}^{\circ}=31.4 \pm 1.3 \mathrm{~kJ} \mathrm{~mol}^{-1}, \Delta \mathrm{S}_{1}^{\circ}=142 \pm 5 \mathrm{~J} \mathrm{~K}^{-1} \mathrm{~mol}^{-1}$

temperature, the slope of $\ln \left(\mathrm{A}_{\mathrm{t}}-\mathrm{A}_{\infty}\right)$ versus time plots at different $\mathrm{Et}_{2} \mathrm{DTC}$ concentrations were found to be constant in the region where the plots are linear (figure 4). For different temperatures, the $\mathrm{k}_{2}$ values were obtained directly from the limiting slopes and are presented in table 3 and the average $10^{5} \mathrm{k}_{2}$ values were $8.93,9.86,10.60$ and $11.48 \mathrm{~s}^{-1}$ at $30,35,40$ and $45^{\circ} \mathrm{C}$ respectively.

\subsection{Effect of change in $\mathrm{pH}$ on the reaction rate}

The reaction was studied at five different $\mathrm{pH}$ values. At a fixed $2.85 \times 10^{-4} \mathrm{~mol} \mathrm{dm}^{-3}$ [complex 1], $5.7 \times$ $10^{-3} \mathrm{~mol} \mathrm{dm}^{-3}$ [Et 2 DTC] and $0.1 \mathrm{~mol} \mathrm{dm}^{-3} \mathrm{NaClO}_{4}$ ionic strength, the $10^{3} \mathrm{k}_{1(\mathrm{obs})}$ values were $2.75,2.68$, $2.65,2.60$ and $2.59 \mathrm{~s}^{-1}$ and $10^{5} \mathrm{k}_{2}$ values were 8.93 , $8.92,8.94,8.90$, and $8.94 \mathrm{~s}^{-1}$ at $\mathrm{pH} 5.5,6.0,6.5,7.0$ and 7.4 respectively at $30^{\circ} \mathrm{C}$. The change in rate may be explained based on two acid dissociation equilibria of $\mathrm{Et}_{2} \mathrm{DTC}$ and the complex, as follows.

Firstly, the $\mathrm{Et}_{2} \mathrm{DTC}\left(\mathrm{pK}_{a}=3.37\right.$ at $\left.25^{\circ} \mathrm{C}\right)$ remains in the anionic form within our studied $\mathrm{pH}$ range. The effect of $\mathrm{pH}$ on rate is therefore due to the change in reactive forms of the reacting complex. Above $\mathrm{pH} 5.5$, $>90 \%$ of the diaqua complex will be in the hydroxoaqua form. As the $\log \mathrm{K}_{\text {dimer }}$ value is 3.12 , it is expected that at $\mathrm{pH}>5.0$, the hydroxo-bridged dimer will be the predominant species $(\sim 85 \%)$ and the effect of change in $\mathrm{pH}$ will be small, as observed experimentally. On the other hand, the $\mathrm{k}_{2 \text { (obs) }}$ values are dependent only on the nature of the ligand during bridge formation. Hence, the $\mathrm{k}_{2(\mathrm{obs})}$ values are independent of $\mathrm{pH}$. Nevertheless, the present kinetic runs were followed at a constant $\mathrm{pH}$ of 7.4 to avoid complications caused by adding an additional parameter of $\left[\mathrm{H}^{+}\right]$to the rate equation.

\subsection{Effect of temperature on the reaction rate}

Four different temperatures were chosen for study and the results are listed in table 4 . The activation parameters for the steps $\mathrm{A} \rightarrow \mathrm{B}$ and $\mathrm{B} \rightarrow \mathrm{C}$ were evaluated from the linear Eyring plots and the results are compared with analogous systems in table 4.

\section{Mechanism and conclusion}

The $\mathrm{Et}_{2} \mathrm{DTC}$ exists as anionic form in the studied $\mathrm{pH}$ range. There are two sulphur atoms in the ligand both of them can coordinate to the metal atom. From the IR data it is clear that both the sulphur atoms of the ligand are involved in bonding with two Pd atoms of the complex 1. This is due to soft nature of both Pd and S atom.

$\mathrm{Et}_{2} \mathrm{DTC}$ has been reported to form complexes with soft metal ions like $\mathrm{Ir}^{+},{ }^{31} \mathrm{Ag}^{+},{ }^{32} \mathrm{Cu}^{+},{ }^{33} \mathrm{Pt}^{2+}{ }^{24}$ using both of its S-donor centers and chelating the metal ion. It is expected that $\mathrm{Et}_{2} \mathrm{DTC}$ would show the same type of bonding mode with the complex in the present reaction condition.

In first stage a rapid equilibrium is established, results an outer sphere association complex between complex 1 and ligand. This proposition is supported by the following facts. First, with an increase in ligand concentration saturation in rate is observed. This is possible only when an outer sphere association complex is formed. Secondly, the low enthalpy of activation and large negative value of entropy of activation strongly suggested the ligand participation in the transition state.

The activation parameters $\left(\Delta \mathrm{H}_{1}^{\neq}=15 \pm 1.2 \mathrm{~kJ} \mathrm{~mol}^{-1}\right.$, $\Delta S_{1}^{\neq}=-239 \pm 5 \mathrm{~J} \mathrm{~K}^{-1} \mathrm{~mol}^{-1}$ for the first and the second steps $\Delta \mathrm{H}_{2}^{\neq}=10.4 \pm 1.5 \mathrm{~kJ} \mathrm{~mol}^{-1}, \Delta \mathrm{S}_{2}^{\neq}=$ $-288 \pm 4 \mathrm{~J} \mathrm{~K}^{-1} \mathrm{~mol}^{-1}$ ) suggest an associative mode 


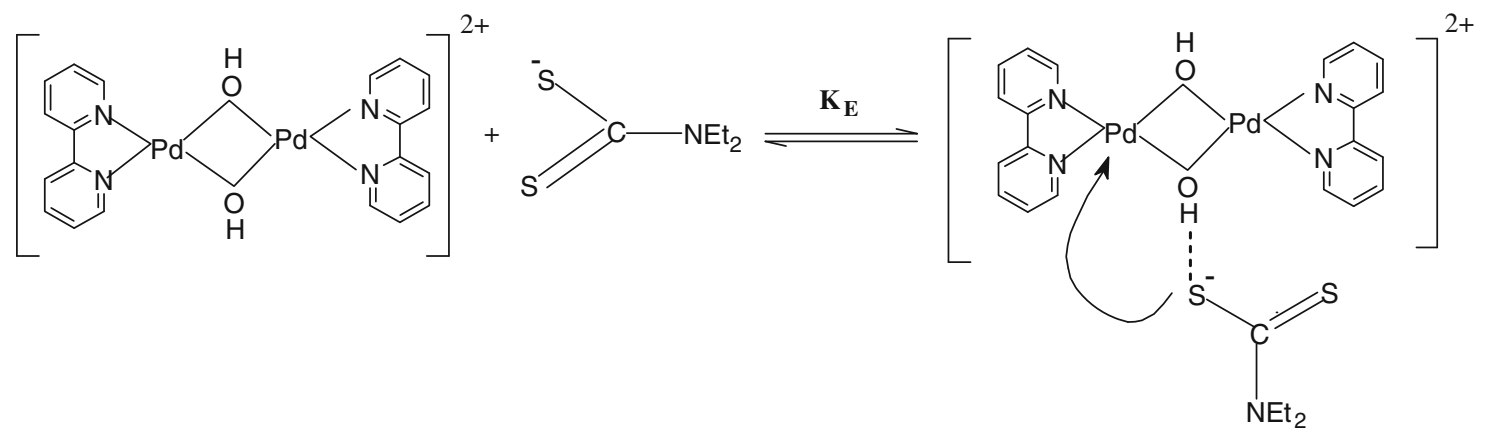

outersphere complex
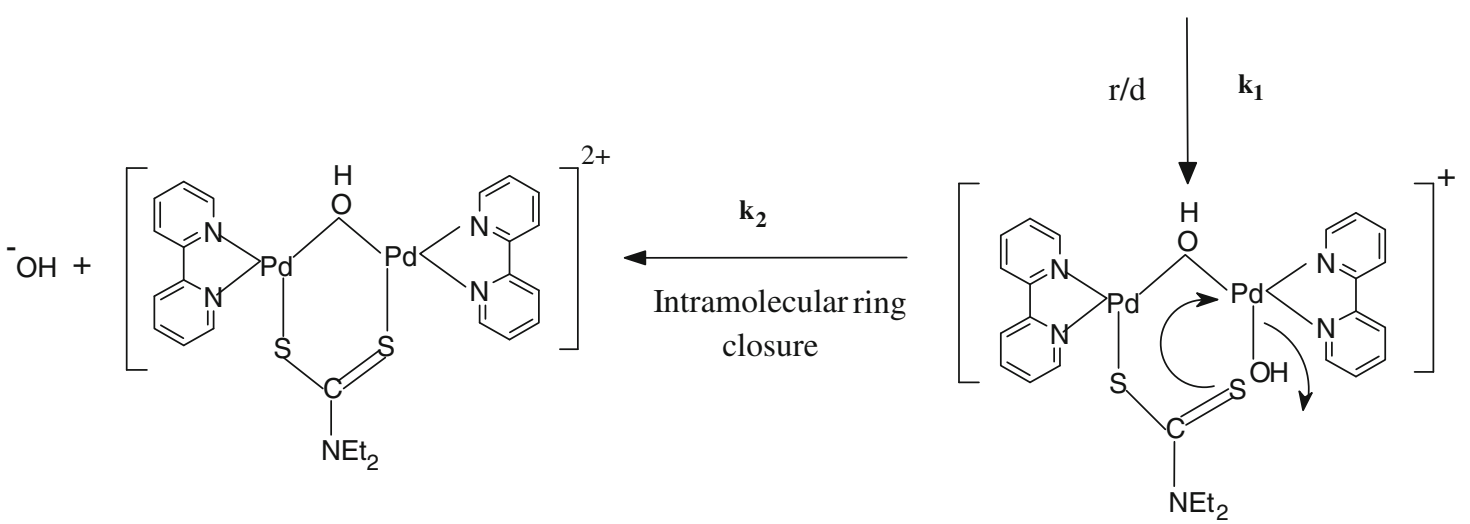

Scheme 4. Proposed mechanism for the interaction of $\mathrm{Et}_{2} \mathrm{DTC}$ with complex $\mathbf{1}$.

of activation for the substitution processes. The low $\Delta \mathrm{H}_{1}^{\neq}$and $\Delta \mathrm{H}_{2}^{\neq}$values imply a good degree of ligand participation in the transition state. The second step is the intramolecular ring closure which is independent on the incoming ligand concentration supported by the value of rate constant $\left(\mathrm{k}_{2}\right)$ for this step was found to be actually independent on ligand concentration.

As the same metal atoms ( $\mathrm{Pd}$ and $\mathrm{S}$ ) are involved in the bond formation in both the steps, the enthalpies make a slight favourable contribution, but the main source of the chelate effect is still to be found in the entropies. The more negative entropy of activation for the second step implies more ordering, indicates more associative nature of the second step. Due to the higher bond dissociation energy of $\mathrm{Pd}-\mathrm{OH}$ (nonbridged) than the $\mathrm{Pd}-\mathrm{OH}$ (bridged) makes the second step more associative.

Previous studies of ligand substitution reactions on this system by different groups proposed a single-step reaction but we have found a two-step process in this case.

Based on the experimental results described above, we propose the reaction mechanism shown in scheme 4 .
It was also found that after completion of the reaction, both the $\mathrm{pH}$ and conductance of the resulting solution had increased, which might be due to loss of one of the bridging $\mathrm{OH}$ groups.

\section{References}

1. Shoukry M M, Shehata M R, Abdel-Razik A and AbdelKarim A T I 1999 Monatshefte für Chemie 130409

2. El-Medani S M, Shohayeb Sh M and Shoukry M M 1998 Transition Met. Chem. 23287

3. Shoukry M M and van Eldik R 1996 J. Chem. Soc., Dalton Trans. 2673

4. Shoukry M M, Hohmann H and van Eldik R 1992 Inorg. Chim. Acta. 187198

5. Shehata M R 2001 Transition Met. Chem. 26198

6. Rosenberg B and Van Camp L 1970 Cancer Res. 30, 1799

7. Davidson J P, Faber P J, Fisher R G, Mansy S, Peresie H J, Rosenberg B and Van Camp L 1975 Cancer Chemother. Pt-1 59287

8. Roberts J J 1981 Adv. Inorg. Bio-chem Acta. 3273

9. Cusumano M and Giannetto A 1997 J. Inorg. Biochem. 65137 
10. Cusumano M, Di Pietro M L, Giannetto A and Vainiglia P A 2005 Eur. J. Inorg. Chem. 2278

11. Borch R F and Pleasants M E 1979 Proc. Natl. Acad. Soc. USA, 766611

12. Borch R F, Katz J C, Leider P H and Pleasants M F 1980 Proc. Natl. Acad. Soc. USA, 775441

13. Mittal R, Jain N and Srivastava T 1989 Inorg. Chim. Acta. 166135

14. Mccormick B J, Jaynes (jun) E N and Kaplon R I 1972 Inorg syn. 13216

15. Bennet G M, Masses A N and Stathan F S 1930 J. Chem. Soc. 1688

16. Hay R W and Basak A K 1982 J. Chem. Soc., Dalton Trans. 1819

17. Nakamoto K 1986 Infrared and Raman Spectra of Inorganic and Coordination Compounds, 4th edn., (Newyork: Wiley-Interscience)

18. Maltese M and Orville-Thomas W J 1976 J. Inorg. Nucl. Chem. 292533

19. Marchal S, Moreno V, Aullon G, Alvarez S, Quiros M., Font-Bardia M and Solans X 1999 Polyhhedron 183675

20. Leka Z, Grujic S A, Tesic Z, Lukic S, Skuban S and Trifunovic S 2004 J. Serb. Chem. Soc. 69(2) 137

21. Weyh J A, Hamm R E 1969 Inorg. Chem. 82298

22. Aspila K I, Joris S J and Chakrabarti C L 1970 J. Phys Chem. 743625
23. Anderegg G and H Wanner H 1986 Inorg. Chim Acta. 113101

24. Wimmer F L and Wimmer S 1988 Inorganica Chimica Acta. 1491

25. Wimmer S, Castan P, Wimmer F L and Johnson P 1988 Inorganica Chimica Acta. 14213

26. (a) Wimmer S, Castan P, Wimmer F L and Johnson N P 1989 J. Chem., Soc. Dalton Trans. 403; (b) Ahmed E L, Sherif A, Shoukry M and van Eldik R 2003 J. Chem. Soc. Dalton Trans. 1425

27. Moi S C, Ghosh A K and De G S 2001 Indian J. Chem. 40A 1187

28. Moi S C, Ghosh A K and De G S 2002 Indian J. Chem. 41A 1188

29. Moi S C and Ghosh A K 2005 Indian J. Chem. 44A 2468

30. Mallick S, Mondal S, Bera B K, Karmakar P, Moi S C and Ghosh A K 2010 Transition Met. Chem. 35469

31. Suardi G, Cleary B P, Duckett S B, Sleigh C, Rau M, Reed E W, Lohman J A B and Eisenberg R 1997 J. Am. Chem. Soc. 1197716

32. Gimeno M, Jones P G, Laguma A and Sarroca C Z 2004 Natutforsch. 59b 1365

33. Jian F, Wang Z, Chem W, Bai Z, Zhang K and Yon X 1999 Polyhedron 182219

34. Mukhopadhyay S K 2008 Transition Met. Chem. 33 739 